\title{
Effect of Sowing Date and Phosphorus Fertilizer Rates on Yield and Yield Components of Sakha 5 Flax Cultivar
}

\author{
Mona M. Hemeid ${ }^{1}$
}

\begin{abstract}
A field research study was conducted at the experimental station of the Faculty of Agriculture, Alexandria University during 2017/2018 and 2018/2019 seasons to investigate the effect of three sowing dates $(1,15$ and 30 November) and three phosphorus fertilizer rates (zero, 36 and $72 \mathrm{~kg} \mathrm{P}_{2} \mathrm{O}_{5} / \mathrm{ha}$.) on straw and seed yields and their components beside seed oil content of Sakha 5 flax cultivar. The obtained results showed significant effects for both sowing dates and phosphorus fertilizer rates, with significant interaction between them on seed index and number of seeds/ capsules in the second season (2018/2019) and seed weight/ plant in the two seasons. The first and second sowing dates were not significantly different from each other in straw yield/ha, but they significantly dominated over the yield of the third sowing date in both seasons. Straw yield/ha ranged from 7.45 to $8.16 \mathrm{t} / \mathrm{ha}$ in the first season and from 7.90 to $8.38 \mathrm{t} / \mathrm{ha}$ in the second season. The sowing date of $15^{\text {th }}$ Nov. significantly increased number of capsules/plant and seed yield/ha more than the other two sowing dates. The highest seed yields/ha were 2.55 and 2.50 t/ha under $15^{\text {th }}$ Nov. sowing date in the two seasons, respectively, followed by $30^{\text {th }}$ Nov. date. Application of $36 \mathrm{~kg} \mathrm{P}_{2} \mathrm{O}_{5} / \mathrm{ha}$ produced the highest means of straw yield and straw yield components but no significant differences were found between the 36 and $\mathbf{7 2}$ $\mathrm{kg}_{2} \mathrm{O}_{5}$ /ha for these traits. The highest means of seed yield and seed yield components were detected under the $36 \mathrm{~kg} \mathrm{P}_{2} \mathrm{O}_{5} / \mathrm{ha}$ rate with significant differences from the highest phosphorus fertilizer rate or zero phosphorus fertilizer. The highest oil percentages were $46.51 \%$ and $46.68 \%$ under the $36 \mathrm{~kg} \mathrm{P}_{2} \mathrm{O}_{5} / \mathrm{ha}$ rate in the two seasons, respectively, followed by the highest rate while the lowest oil percentages were $45.09 \%$ and $45.08 \%$ under zero phosphorus fertilizer in the two seasons, respectively. Regarding the significant interaction effect, the obtained results indicated that $30^{\text {th }}$ Nov. with $36 \mathrm{~kg} \mathrm{P}_{2} \mathrm{O}_{5}$ /ha gave higher values of seed index and number of seeds/ capsules in the second season, seed weight/ plant increased with both $15^{\text {th }}$ or $30^{\text {th }}$ Nov. under $36 \mathrm{~kg} \mathrm{P}_{2} \mathrm{O}_{5}$ /ha in the first season, whereas in the second season the highest value was obtained for $15^{\text {th }}$ Nov. under $36 \mathrm{~kg} \mathrm{P}_{2} \mathrm{O}_{5} / \mathrm{ha}$.
\end{abstract}

Key words: Phosphorus, Sowing date, Straw yield, Flax, Seed yield components.

\section{INTRODUCTION}

Flax (Linum usitatisimum L.), is an important seed and fiber crop and has several industrial uses and high impact economic value for the farmer (El-Nakhlawy, 1995b). Linseed oil is of highly unsaturated fatty acids content, especially linolenic, linoleic and oleic fatty acids, accordingly it is a good source for Omega 6 and Omega 3 antioxidants (El-Nakhlawy, 1995 a, Morris, 2007 and El-Nakhlawy and Shiboob, 2011). In addition it has many industrial uses, including paints, ink and human food, while linseed meal is used for livestock feed. In Egypt, flax is cultivated for both fiber and seeds (FAO, 2019).

Improving flax production is a continuous process, especially with the recent climatic changes affecting the entire globe. Recent fluctuation in temperatures can affect the suitable sowing date of flax and many important agronomic traits including total and technical plant lengths, number of capsules, seed weight/plant and straw and seed yields/ha beside seed oil content. The effects of sowing date were due to the heat units, rainfall and relative humidity during plant growth period. Delaying sowing displaces seed filling to periods of high temperature, which affect their oil content and yield (Dybing et al., 1988, Casa et al., 1999 and Abd El-Mohsen et al., 2013). Seed yield and seed yield components, time to reach harvest maturity, oil content, and oil composition depend mainly on the temperature during plant development. Other factors such as seed moisture at harvest may also influence the final seed oil content and the oil composition (Adugna and Labuschagne, 2003). Seed and oil production are known to be conditioned by the optimum planting date. Because of its geographical location, weather conditions, and soil characteristics, the optimum planting date in Egypt is mid-November (Agriculture Extension, 2010), when temperatures are more conducive to the growth and development of the crop allowing a proper flowering to maturity period.

\footnotetext{
DOI: 10.21608/ASEJAIQJSAE.2020.112089

${ }^{1}$ Crop Science Department, Faculty of Agriculture, Alexandria University, Alexandria, Egypt.

* Corresponding author's email: mona.mohamed@alexu.edu.eg

Received August 17, 2020, Accepted, September 12, 2020.
} 
Phosphorus must be available to the crop in adequate amounts during the growing season. Plants need phosphorus throughout their life cycle, especially during early growth stages for cell division and during maturity stage for seed formation and increase seed weight. (Lafoand et al., 2003). Phosphorus is mobile in the plant, so it is absorbed during early growth and is later redirected for use in seed formation. The medium to high soil phosphorus levels to optimize flax yields were recommended (Mousavi, 2011). Phosphorus fertilizer can increase seed yield (Grant et al., 2009; Rogério et al., 2013 and Xie et al., 2014), dry matter accumulation and distribution (Fleisher et al., 2013), and phosphorus accumulation and translocation. Phosphorus fertilizer supply increased photosynthesis in the leaf of oilseed flax, which enhanced source capacity and the seed as the most active sink for photoassimilates (Xie et al., 2014). Therefore, added phosphorus increased seed yield by enhancing dry matter translocation to the seed (Jiao et al., 2007 and Xie et al., 2014). Furthermore, phosphorus supply improved seed yield by increasing the number of capsules per plant (Hocking and Pinkerton, 1993) and seeds per capsule.

The aim of this study was to evaluate the effect of sowing dates and phosphorus fertilizer rate on seed and straw yields and their components beside seed oil content of Sakha 5 flax cultivar.

\section{MATERIALS AND METHODS}

Field experiments were conducted at the experimental station of the Faculty of Agriculture, Alexandria University in Abbis region, during the two successive winter seasons of 2017/2018 and 2018/2019, to investigate the effect of three sowing dates and three phosphorus fertilizer rates on straw and seed yields and their components of the flax cultivar Sakha 5 . Experiments were laid in split plot design with four replicates; the main plots included three sowing dates $\left(1^{\text {st }}, 15^{\text {th }}\right.$ and $30^{\text {th }}$ November $)$. The subplots were occupied with three phosphorus rates namely; control (zero phosphorus fertilizer), 36 and $72 \mathrm{~kg} \mathrm{P}_{2} \mathrm{O}_{5} / \mathrm{ha}$. Mineral phosphorus fertilizer was in the form of calcium super phosphate $\left(15.5 \% \mathrm{P}_{2} \mathrm{O}_{5}\right)$ added before sowing and during soil preparation in both seasons. The soil of the experiment was clay and characterized with $8.5 \mathrm{pH}, 2.21 \mathrm{dSm}^{-1}$ as EC, $1.7 \%$ organic matter, $4.5 \%$ available nitrogen, $10.2 \%$ available phosphorus and $22.2 \%$ available potassium as an average of the two seasons. Each sub plot unit area was $6 \mathrm{~m}^{2}(2 \times 3 \mathrm{~m})$. The preceding summer crop was sunflower in the first season and maize in the second season. Flax seeds were drilled on rows $0.15 \mathrm{~m}$ apart at a seeding rate of 120 $\mathrm{kg} / \mathrm{ha}$. Nitrogen fertilizer was added at $110 \mathrm{~kg} \mathrm{~N} / \mathrm{ha}$ in the form of ammonium nitrate (33.5\%) in three equal doses before the $1^{\text {st }}$,the $2^{\text {nd }}$ and the $3^{\text {rd }}$ irrigation, Potassium was added at $60 \mathrm{~kg} \mathrm{~K}_{2} \mathrm{O} /$ ha before sowing .Other recommended cultural practices for flax production were done as recommendations of the Egyptian Ministry of Agriculture and Land Reclamation.

At harvest, 10 guarded random plants from each sub plot were harvested to determine the following traits: plant height $(\mathrm{cm})$, technical length $(\mathrm{cm})$, fruiting zone length $(\mathrm{cm})$, stem diameter $(\mathrm{mm})$, number of capsules/plant, number of seeds/capsule, straw weight/plant $(\mathrm{g})$ and seed weight/plant $(\mathrm{g})$. Straw yield/ha and seed yield/ha were determined from a random area of one square meter in each sub plot then converted into t/ha. One thousand random seeds were weighed as an average of two samples from each sub plot as seed index. Seed oil content (\%) was determined from a random dried seed sample from each sub plot by Soxhlet Instrument using N-Hexane (B.P. $60^{\circ} \mathrm{C}$ ) as an organic solvent according to (AOCS, 2004).

The obtained data were statistically analyzed through analysis of variance procedures to test the significance of the studied factors and their interaction; then the means of the significant factors or interactions were compared using least significant difference test (LSD $\leq 0.05$ ) (El-Nakhlawy, 2010) using SAS program version 9.1.3 (SAS, 2007).

\section{RESULTS AND DISCUSSION}

\section{Analysis of variance:}

The results of the analysis of variance for the studied flax traits as affected by the three sowing dates, three phosphorus fertilizer rates and their interaction during the two successive seasons (2017/18 and 2018/19) are presented in tables (1 and 2) according to the related flax traits. Straw yield and its components, beside the fruiting zone length, are presented in table (1), while seed yield and its components, beside seed oil content traits are presented in Table (2).

\subsection{Straw yield and its components:}

Analysis of variance (Table 1) showed significant effects for sowing date on flax plant height, technical length, fruiting zone length, straw weight/plant and straw yield/ha. in both seasons.

Concerning phosphorus fertilizer rate effects, the presented data in table (1) indicated that phosphorus fertilizer rates had significant effect on all studied traits, except stem diameter in the two seasons.

No significant effects for the interaction between sowing date and phosphorus fertilizer rate were detected for all presented traits in table (1) in the two growing seasons. 
Table 1. Analysis of variance for Plant height, Technical length, Fruiting zone length, Stem diameter, Straw weight/plant and Straw yield/ha as affected by sowing dates, phosphorus fertilizer rates and their interactions during 2017/2018 and 2018/2019 seasons.

\begin{tabular}{|c|c|c|c|c|c|c|c|c|c|c|c|c|c|}
\hline \multirow[t]{2}{*}{ Source of variation } & \multirow[t]{2}{*}{ d.f } & \multicolumn{2}{|c|}{ Plant height } & \multicolumn{2}{|c|}{ Technical length } & \multicolumn{2}{|c|}{ Fruiting zone length } & \multicolumn{2}{|c|}{ Stem diameter } & \multicolumn{2}{|c|}{ Straw weight/plant } & \multicolumn{2}{|c|}{ Straw yield/ha } \\
\hline & & $2017 / 18$ & $2018 / 19$ & $2017 / 18$ & $2018 / 19$ & $2017 / 18$ & $2018 / 19$ & $2017 / 18$ & $2018 / 19$ & $2017 / 18$ & $2018 / 19$ & $2017 / 18$ & $2018 / 19$ \\
\hline Replicates & 3 & 20.15 & 34.61 & 2.03 & 3.39 & 1.68 & 1.27 & 0.03 & 0.04 & 0.01 & 0.03 & 0.02 & 0.06 \\
\hline Sowing dates (A) & 2 & $725.01^{* *}$ & $454.99^{*}$ & $46.16^{*}$ & $53.33^{*}$ & $38.94^{*}$ & $41.46^{*}$ & $0.08 \mathrm{~ns}$ & $0.06 \mathrm{~ns}$ & $0.41^{* * *}$ & $0.25^{* *}$ & $0.38^{*}$ & $0.42^{*}$ \\
\hline Error (a) & 6 & 56.45 & 60.39 & 5.98 & 7.03 & 4.12 & 5.52 & 0.05 & 0.04 & 0.03 & 0.01 & 0.04 & 0.06 \\
\hline Phosphorus rates (B) & 2 & $350.99 *$ & $22.74 *$ & $21.64 *$ & $46.26^{*}$ & $20.62 *$ & $19.07 *$ & $0.04 \mathrm{~ns}$ & $0.09 \mathrm{~ns}$ & $0.07 *$ & $0.06^{*}$ & $0.04 *$ & $0.05^{*}$ \\
\hline $\mathrm{AxB}$ & 4 & $68.78 \mathrm{~ns}$ & $9.93 \mathrm{~ns}$ & $2.45 \mathrm{~ns}$ & $6.5 \mathrm{~ns}$ & $5.06 \mathrm{~ns}$ & $5.81 \mathrm{~ns}$ & $0.03 \mathrm{~ns}$ & $0.05 \mathrm{~ns}$ & $0.032 \mathrm{~ns}$ & $0.019 \mathrm{~ns}$ & $0.02 \mathrm{~ns}$ & $0.01 \mathrm{~ns}$ \\
\hline Error (b) & 18 & 43.12 & 45.21 & 4.13 & 5.91 & 3.61 & 4.54 & 0.02 & 0.03 & 0.013 & 0.013 & 0.01 & 0.01 \\
\hline
\end{tabular}

*,**: significant at 0.05 and 0.01 levels of probability, respectively.

Table 2. Analysis of variance for Seed index, No. of seeds/ capsule, No. of capsules/plant, Seed weight/plant, Seed yield/ ha and Seed oil content as affected by sowing dates, phosphorus fertilizer rates and their interactions during 2017/2018 and 2018/2019 seasons.

\begin{tabular}{|c|c|c|c|c|c|c|c|c|c|c|c|c|c|}
\hline \multirow[t]{2}{*}{ Source of variation } & \multirow[t]{2}{*}{ d.f } & \multicolumn{2}{|c|}{ Seed index } & \multicolumn{2}{|c|}{ No. of seeds/ capsule } & \multicolumn{2}{|c|}{$\begin{array}{c}\text { No. of } \\
\text { capsules/plant }\end{array}$} & \multicolumn{2}{|c|}{ Seed weight/plant } & \multicolumn{2}{|c|}{ Seed yield/ ha } & \multicolumn{2}{|c|}{ Seed oil content } \\
\hline & & 2017/18 & 2018/19 & 2017/18 & 2018/19 & 2017/18 & 2018/19 & 2017/18 & 2018/19 & 2017/18 & $18 / 19$ & $17 / 18$ & 18/19 \\
\hline Replicates & 3 & 0.015 & 0.12 & 0.05 & 0.056 & 0.18 & 0.37 & 0.032 & 0.005 & $0.02 \mathrm{~ns}$ & $0.01 \mathrm{~ns}$ & 0.22 & 3.89 \\
\hline Sowing dates (A) & 2 & $5.6^{* *}$ & $3.99^{*}$ & $0.29^{*}$ & $0.703^{* *}$ & $2.66^{*}$ & $2.03^{* *}$ & $0.084^{* *}$ & $0.13^{* *}$ & $0.87^{* *}$ & $0.77^{* *}$ & $4.01 \mathrm{~ns}$ & $1.15 \mathrm{~ns}$ \\
\hline Error (a) & 6 & 0.28 & 0.40 & 0.05 & 0.056 & 0.28 & 0.26 & 0.005 & 0.004 & 0.11 & 0.12 & 1.01 & 0.74 \\
\hline Phosphorus rates (B) & 2 & $0.86^{* *}$ & $2.52^{* *}$ & $0.53^{* *}$ & $0.514^{* *}$ & $1.70^{* *}$ & $2.76^{* *}$ & $0.633^{* *}$ & $0.258^{*}$ & $0.26^{*}$ & $0.39^{*}$ & $6.38^{* *}$ & $7.70^{* *}$ \\
\hline $\mathrm{AxB}$ & 4 & $0.151 \mathrm{~ns}$ & $1.02^{* *}$ & $0.05 \mathrm{~ns}$ & $0.258^{* *}$ & $0.29 \mathrm{~ns}$ & $0.32 \mathrm{~ns}$ & $0.015^{* *}$ & $0.051^{* *}$ & $0.05 \mathrm{~ns}$ & $0.03 \mathrm{~ns}$ & $1.23 \mathrm{~ns}$ & $0.95 \mathrm{~ns}$ \\
\hline Error (b) & 18 & 0.105 & 0.14 & 0.05 & 0.03 & 0.14 & 0.18 & 0.002 & 0.001 & 0.09 & 0.08 & 0.83 & 0.85 \\
\hline
\end{tabular}

*, **: significant at 0.05 and 0.01 levels of probability, respectively. 


\subsection{Seed Yield and its components:}

Sowing date significantly affected seed yield/ha and all seed yield components, i.e., seed index, number of seeds/capsule, number of capsules/plant, and seed weight/plant as shown in Table (2).

Significant effects were found for phosphorus fertilizer rate on seed yield and all seed yield components. No significant effects were found for the interaction between sowing date and phosphorus fertilizer rate on seed yield/ha and seed yield components, except seed index and number of seeds/capsule in the second season and seed weight/ plant in both seasons (Table 2). As for seed oil content under the studied factors and their interaction, analysis of variance showed insignificant effects for sowing date and the interaction on that character, while significant effects for phosphorus fertilizer rate on seed oil content were observed during both seasons (Table 2).

\section{Comparisons between means:}

\subsection{Effect of sowing dates:}

\subsubsection{Effect of sowing date on straw yield and its components:}

The statistical comparisons between the studied means of straw yield and its components during both seasons (Table 3 ) showed that sowing flax on $1^{\text {st }}$ November produced the tallest plants and tallest technical stem length in both seasons, without significant differences from the $15^{\text {th }}$ November sowing date but significantly different from the Nov. $30^{\text {th }}$ sowing date. Under the first sowing date, plant heights were $102.53 \mathrm{~cm}$ and $99.87 \mathrm{~cm}$ in the first and second seasons, respectively. Plant heights under the third sowing date were 93.89 and $91.29 \mathrm{~cm}$, in both seasons, respectively. Technical length means ranged from 53.93 to $68.36 \mathrm{~cm}$ in the first season and from 60.07 to $65.93 \mathrm{~cm}$ in the second season. No significant differences were found between the means of stem diameters under the three studied sowing dates in both seasons. Stem diameter ranged from 2.14 to $2.16 \mathrm{~mm}$ in the first season and from 2.11 to $2.13 \mathrm{~mm}$ in the second season. The $1^{\text {st }}$ and $2^{\text {nd }}$ sowing dates were not significantly different in straw weight/plant but they significantly dominated over the third sowing date in both seasons. Straw weight means ranged from 1.38 to $1.61 \mathrm{~g}$ in the first season and from 1.48 to $1.67 \mathrm{~g}$ in the second season under the $30^{\text {th }}$ Nov. and $1^{\text {st }}$ Nov. sowing dates, respectively. The response of straw yield components to the studied sowing dates was reflected in the straw yield/ha response. The first and second sowing dates were not significantly different from each other in straw yield/ha but they significantly dominated over the yield of the third sowing date in both seasons. Straw yield/ha ranged from 7.45 to 8.16 t/ha in the first season and from 7.90 to $8.38 \mathrm{t} / \mathrm{ha}$ in the second season (Table $3)$.

\subsubsection{Effect of sowing dates on seed yield and its components:}

The tallest fruiting zone length was found under the $15^{\text {th }}$ Nov. sowing date without significant differences from the $30^{\text {th }}$ Nov. but they were significantly differed than the $1^{\text {st }}$ Nov. Fruiting zone length ranged from 28.41 to $34.42 \mathrm{~cm}$ in the first season and from 28.90 to 33.54 $\mathrm{cm}$ in the second season (Table 3). The presented data in Table (4) indicated that the $15^{\text {th }}$ Nov. sowing date dominated over the other two sowing dates in all seed yield components and seed yield/ha and the lowest values of seed yield/ha and its components were produced from the $1^{\text {st }}$ Nov. sowing date. As for seed index and number of seeds/plant traits, the statistical comparison showed no significant differences between the $15^{\text {th }}$ and $30^{\text {th }}$ Nov. sowing dates but they were significantly higher than the $1^{\text {st }}$ Nov. sowing date in both seasons. Seed index ranged from 8.57 to $9.73 \mathrm{~g}$ in the first season and from 9.83 to $10.87 \mathrm{~g}$ in the second season. Number of seeds/capsule ranged from 9.29 to 9.59 in the first season and from 9.39 to 9.83 in the second season. Sowing date of $15^{\text {th }}$ Nov. significantly increased number of capsules/plant, seed weight/plant and seed yield/ha compared to the other two sowing dates, followed by the third date of sowing in the two seasons. Number of capsules/plant ranged from 18.44 to 20.83 in the first season and from 17.94 to 19.67 in the second season. Seed weight /plant ranged from 0.69 to $0.89 \mathrm{~g}$ and from 0.62 to $0.87 \mathrm{~g}$ in the first and second seasons, respectively. The highest seed yields/ha were 2.55 and $2.50 \mathrm{t} / \mathrm{ha}$ in $15^{\text {th }}$ Nov. sowing date in the two seasons, respectively, followed by $30^{\text {th }}$ Nov. sowing date with seed yields of 2.23 and 2.20 t/ha in the two seasons, respectively, while the lowest seed yield resulted from the $1^{\text {st }}$ Nov. sowing date with values of 1.95 and $1.81 \mathrm{t} / \mathrm{ha}$ in the first and second seasons, respectively.

Seed oil content did not significantly differ under the three studied sowing dates in both seasons. Oil content ranged from 45.13 to $46.29 \%$ in the first season and from 45.31 to $46.31 \%$ in the second season (Table 4).

The obtained results showed the superiority of the $15^{\text {th }}$ Nov. sowing date in seed and straw yields beside their yield components and oil content. These results can be discussed as due to the positive effects of the mid-November sowing date on the flax plant growth through increasing photosynthesis and enhancing vegetative growth. 
Table 3. Means for plant height, technical length, fruiting zone length, stem diameter, straw weight/plant and straw yield/ha during $2017 / 2018$ and 2018/2019 seasons under the effect of sowing dates.

\begin{tabular}{|c|c|c|c|c|c|c|c|c|c|c|c|c|}
\hline Sowing date & \multicolumn{2}{|c|}{$\begin{array}{l}\text { Plant height } \\
\text { (cm) }\end{array}$} & \multicolumn{2}{|c|}{$\begin{array}{l}\text { Technical length } \\
(\mathrm{cm})\end{array}$} & \multicolumn{2}{|c|}{$\begin{array}{l}\text { Fruiting zone length } \\
(\mathrm{cm})\end{array}$} & \multicolumn{2}{|c|}{$\begin{array}{l}\text { Stem diameter } \\
(\mathrm{mm})\end{array}$} & \multicolumn{2}{|c|}{$\begin{array}{c}\text { Straw weight/plant } \\
\text { (g) }\end{array}$} & \multicolumn{2}{|c|}{$\begin{array}{c}\text { Straw yield/ ha. } \\
\text { (t) }\end{array}$} \\
\hline $1^{\text {st }}$ Nov. & $102.53 \mathrm{a}^{*}$ & $99.87 \mathrm{a}$ & $68.36 \mathrm{a}$ & $65.93 \mathrm{a}$ & $28.41 \mathrm{~b}$ & $28.90 \mathrm{~b}$ & $2.14 \mathrm{a}$ & $2.13 \mathrm{a}$ & $1.61 \mathrm{a}$ & $1.67 \mathrm{a}$ & $8.16 \mathrm{a}$ & $8.38 \mathrm{a}$ \\
\hline $15^{\text {th }}$ Nov. & $98.71 \mathrm{ab}$ & $94.89 \mathrm{ab}$ & $66.30 \mathrm{a}$ & $63.51 \mathrm{a}$ & $34.42 \mathrm{a}$ & $33.54 \mathrm{a}$ & $2.16 \mathrm{a}$ & $2.12 \mathrm{a}$ & $1.59 \mathrm{a}$ & $1.61 \mathrm{a}$ & $8.00 \mathrm{a}$ & $8.19 \mathrm{a}$ \\
\hline L.S.D.(0.05) & 7.50 & 7.76 & 2.44 & 2.65 & 2.03 & 2.35 & ns & ns & 0.18 & 0.10 & 0.20 & 0.24 \\
\hline
\end{tabular}

n.s: not significant at $\mathrm{P} \leq 0.05$.

*: Means followed by the same letter(s) within the same column are insignificantly different at 0.05 level of probability.

Table 4. Means for Seed index, No. of seeds/ capsule, No. of capsules/plant, Seed weight/plant, Seed yield/ ha and Seed oil content during 2017/2018 and 2018/2019 seasons under the effect of sowing dates.

\begin{tabular}{|c|c|c|c|c|c|c|c|c|c|c|c|c|}
\hline \multirow[t]{2}{*}{ Sowing date } & \multicolumn{2}{|c|}{$\begin{array}{c}\text { Seed index } \\
\text { (g) }\end{array}$} & \multicolumn{2}{|c|}{ No. of seeds/ capsule } & \multicolumn{2}{|c|}{ No. of capsules/plant } & \multicolumn{2}{|c|}{$\begin{array}{c}\text { Seed weight/plant } \\
\text { (g) }\end{array}$} & \multicolumn{2}{|c|}{$\begin{array}{c}\text { Seed yield/ha. } \\
(\mathrm{t} / \mathrm{ha})\end{array}$} & \multicolumn{2}{|c|}{$\begin{array}{c}\text { Seed oil } \\
(\%)\end{array}$} \\
\hline & 2017/18 & 2018/19 & $2017 / 18$ & 2018/19 & 2017/18 & 2018/19 & 2017/18 & 2018/19 & 2017/18 & 2018/19 & 2017/18 & 2018/19 \\
\hline $1^{\text {st }}$ Nov. & $8.57 b^{*}$ & $9.83 \mathrm{~b}$ & $9.29 \mathrm{~b}$ & $9.39 \mathrm{~b}$ & $18.44 \mathrm{c}$ & $17.94 \mathrm{c}$ & $0.69 \mathrm{c}$ & $0.62 \mathrm{c}$ & $1.95 \mathrm{c}$ & $1.81 \mathrm{c}$ & $45.13 \mathrm{a}$ & $45.31 \mathrm{a}$ \\
\hline $15^{\text {th }}$ Nov. & $9.73 \mathrm{a}$ & $10.87 \mathrm{a}$ & $9.59 \mathrm{a}$ & $9.83 \mathrm{a}$ & $20.83 \mathrm{a}$ & $19.67 \mathrm{a}$ & $0.89 \mathrm{a}$ & $0.87 \mathrm{a}$ & $2.55 \mathrm{a}$ & $2.50 \mathrm{a}$ & $46.29 \mathrm{a}$ & $46.31 \mathrm{a}$ \\
\hline $30^{\text {th }}$ Nov. & $9.61 \mathrm{a}$ & $10.79 \mathrm{a}$ & $9.50 \mathrm{ab}$ & $9.79 \mathrm{a}$ & $19.65 \mathrm{~b}$ & $18.64 \mathrm{~b}$ & $0.81 \mathrm{~b}$ & $0.76 \mathrm{~b}$ & $2.23 \mathrm{~b}$ & $2.20 \mathrm{~b}$ & $45.70 \mathrm{a}$ & $45.94 \mathrm{a}$ \\
\hline L.S.D.(0.05) & 0.53 & 0.63 & 0.22 & 0.24 & 0.52 & 0.51 & 0.07 & 0.06 & 0.27 & 0.28 & ns & ns \\
\hline
\end{tabular}

*: Means followed by the same letter(s) within the same column are insignificantly different at 0.05 level of probability. 
The optimum planting date in Egypt is the midNovember, when temperatures are more adequate to the growth and development of the crop allowing for a proper flowering to maturity period. Delaying planting date will shift seed filling stage to periods of high temperature, which will reduce their oil content and yield. These results are in agreement with those obtained by Garsid, (2004), Lafond et al., (2008), ElRefaey et al., (2010), Ottai et al., (2011), Mirshekari et al., (2012). Abd El Mohsen et al., (2013) and Askar et al., (2013).

\subsection{Effect of phosphorus fertilizer rates:}

\subsubsection{Effect of phosphorus fertilizer rates on straw yield and its components:}

As shown in Table (5), a significant increase in all straw yield components, beside straw yield/ha, was recorded as phosphorus fertilizer rate increased. The highest means were found under the application of 36 $\mathrm{kg} \mathrm{P}_{2} \mathrm{O}_{5} / \mathrm{ha}$ with no significant differences found between the 36 and $72 \mathrm{~kg} \mathrm{P}_{2} \mathrm{O}_{5}$ /ha for all traits. The means of the straw yield components under the rate of $36 \mathrm{kgP}_{2} \mathrm{O}_{5} / \mathrm{ha}$ in the first season were $103.0 \mathrm{~cm}, 68.17$ $\mathrm{cm}, 2.29 \mathrm{~mm}$ and $1.69 \mathrm{~g}$, however the means in the second season were $98.67 \mathrm{~cm}, 65.66 \mathrm{~cm}, 2.20 \mathrm{~mm}$ and $1.74 \mathrm{~g}$ for plant height, technical length, stem diameter and straw weight/plant, respectively. Straw yield/ha means in the $1^{\text {st }}$ and $2^{\text {nd }}$ seasons, respectively were 8.11 and $8.32 \mathrm{t} / \mathrm{ha}$ under $36 \mathrm{~kg} \mathrm{P}_{2} \mathrm{O}_{5} /$ ha, followed by 8.09 and $8.27 \mathrm{t} / \mathrm{ha}$ under the $72 \mathrm{~kg} \mathrm{P}_{2} \mathrm{O}_{5} / \mathrm{ha}$, while the lowest yield means were recorded without phosphorus fertilizer.

\subsubsection{Effect of phosphorus fertilizer rates on seed yield and its components:}

The highest means of seed yield and seed yield components were detected under the $36 \mathrm{~kg} \mathrm{P}_{2} \mathrm{O}_{5}$ rate with significant differences from the highest phosphorus fertilizer rate $\left(72 \mathrm{~kg} \mathrm{P}_{2} \mathrm{O}_{5} / \mathrm{ha}\right)$ or zero phosphorus fertilizer. The highest phosphorus fertilizer rate ranked the second and significantly dominated over the zero phosphorus fertilizer. The highest seed yields/ha were 2.514 and 2.362 t/ha (with 37.5 and $31.0 \%$ increase compared to zero phosphorus fertilizer) under the $36 \mathrm{~kg}$ $\mathrm{P}_{2} \mathrm{O}_{5} / \mathrm{ha}$ in the first and second seasons, respectively, followed by 2.111 and 2.12 t/ha under the highest phosphorus fertilizer rate in both seasons, respectively, while the lowest seed yields /ha in the two seasons were produced without phosphorus application (Table 6). Flax plants fertilized with $36 \mathrm{~kg} \mathrm{P}_{2} \mathrm{O}_{5} / \mathrm{ha}$, showed an increase, compared to no phosphorus fertilization, in the two seasons respectively, of 25.4 and $28.4 \%$ for fruiting zone length, 5.6 and $9.17 \%$ for seed index, 5.1 and $4.4 \%$ for number of seeds/capsule, 12.16 and $22.8 \%$ for number of capsules/plant, and 74.6 and $47.54 \%$ for seed weight/plant (Table 6). Also, the behavior of seed oil content to rate of applied phosphorus was similar to the other seed yield components. The highest oil contents were 46.51 and $46.68 \%$ under the $36 \mathrm{~kg} \mathrm{P}_{2} \mathrm{O}_{5}$ rate in the two seasons, respectively, followed by the highest rate, while the lowest oil percentages were 45.09 and $45.08 \%$ resulted under zero phosphorus fertilizer.

These results may be due to the role of phosphorus in plant growth during the vegetative and reproductive stages. Phosphorus plays a vital role in several biological processes in plants including energy production and storage, which controls growth of vegetative organs (You et al., 2007), flowering and seed setting (Mengel and Frnest, 2010 and Choudhary et al., 2016). Translocation of photosynthates from leaves (source) to seeds (sink) is dependent on energy supplied by phosphorus compound (ATP and ADP), thus affecting seed setting and seed weight (Leilah et al., 2003). Adequate phosphorus fertilization rates, medium to high, were reported to increase seed yield and its components (Lafoand et al., 2003, Jiao et al., 2007, Mousavi, 2011and Xie et al., 2014). The three main yield components of seed yield, i.e., number of capsules/plant, number of seeds/capsule and seed weight increased with application of phosphorus with adequate rates (Hocking and Pinkerton, 1993 and Grant et al., 2009). The increase in those characters will lead to the increase in seed yield (Fleisher et al., 2013, Rogério et al., 2013 and Xie et al., 2016). Moreover straw, and hence fiber, production of flax were found to be affected by phosphorus availability to plants, and increased with medium to high phosphorus applications ( Leilah et al., 2003).

\subsection{Effect of the interaction between sowing dates and phosphorus fertilizer rates:}

Results in Table (7) indicated that the third sowing date (30 $30^{\text {th }}$ Nov.) with $36 \mathrm{~kg} \mathrm{P}_{2} \mathrm{O}_{5} /$ ha superiority in traits (seed index and number of seeds/ capsule) by 22.3 and $9.42 \%$, respectively, increase compared to first sowing date ( $1^{\text {st }}$ Nov.) without phosphorus fertilization (zero $\mathrm{kg}$ $\mathrm{P}_{2} \mathrm{O}_{5} /$ ha), while seed weight/plant, in first season, both of $15^{\text {th }}$ and $30^{\text {th }}$ Nov. with $36 \mathrm{~kg} \mathrm{P}_{2} \mathrm{O}_{5} /$ ha gave the higher seed weight/plant (1.19 and $1.16 \mathrm{~g}$, respectively, whereas in the second season, $15^{\text {th }}$ Nov. sowing date with $36 \mathrm{~kg} \mathrm{P}_{2} \mathrm{O}_{5} /$ ha gave a higher seed weight/plant $1.12 \mathrm{~g}$ followed by $30^{\text {th }}$ Nov. $(0.94 \mathrm{~g})$ with significant differences. The lowest values of seed weight / plant were 0.55 and $0.53 \mathrm{~g}$ in two seasons with $1^{\text {st }}$ Nov. without phosphorus fertilization. The interaction effects were obvious in the response of both seed index and number of seeds/capsule to phosphorus fertilizer rates at the different sowing dates. In the first and second sowing dates, there were no significant differences between phosphorus fertilizer rates for the two traits. 
Table 5. Means of Plant height, Technical length, Fruiting zone length, Stem diameter, Straw weight/plant and Straw yield/ha during 2017/2018 and 2018/2019 seasons under the effect of phosphorus fertilizer rates.

\begin{tabular}{|c|c|c|c|c|c|c|c|c|c|c|c|c|}
\hline \multirow{2}{*}{ 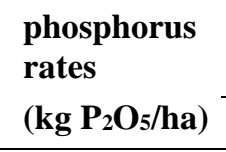 } & \multicolumn{2}{|c|}{$\begin{array}{c}\text { Plant height } \\
(\mathbf{c m})\end{array}$} & \multicolumn{2}{|c|}{$\begin{array}{c}\text { Technical length } \\
(\mathrm{cm})\end{array}$} & \multicolumn{2}{|c|}{$\begin{array}{l}\text { Fruiting zone length } \\
\text { (cm) }\end{array}$} & \multicolumn{2}{|c|}{$\begin{array}{c}\text { Stem diameter } \\
(\mathbf{m m})\end{array}$} & \multicolumn{2}{|c|}{$\begin{array}{c}\text { Straw weight/plant } \\
\text { (g) }\end{array}$} & \multicolumn{2}{|c|}{$\begin{array}{l}\text { Straw yield/ ha. } \\
\text { (t) }\end{array}$} \\
\hline & $2017 / 18$ & $2018 / 19$ & $2017 / 18$ & $2018 / 19$ & $2017 / 18$ & 2018/19 & $2017 / 18$ & 2018/19 & $2017 / 18$ & 2018/19 & $2017 / 18$ & $2018 / 19$ \\
\hline Zero & $93.96 b^{*}$ & $90.52 b$ & $63.8 \mathrm{~b}$ & $60.33 \mathrm{~b}$ & $28.40 \mathrm{c}$ & $27.04 \mathrm{c}$ & $1.98 \mathrm{~b}$ & $2.01 \mathrm{~b}$ & $1.32 \mathrm{~b}$ & $1.33 \mathrm{~b}$ & $7.90 \mathrm{~b}$ & $7.90 \mathrm{~b}$ \\
\hline 72 & $98.13 \mathrm{ab}$ & $95.83 \mathrm{ab}$ & $66.62 \mathrm{a}$ & $64.30 \mathrm{a}$ & $32.22 \mathrm{~b}$ & $32.31 \mathrm{~b}$ & $2.19 \mathrm{a}$ & $2.16 \mathrm{a}$ & $1.67 \mathrm{a}$ & $1.65 \mathrm{a}$ & $8.09 \mathrm{a}$ & $8.27 \mathrm{a}$ \\
\hline L.S.D.(0.05) & 5.63 & 5.77 & 1.74 & 2.08 & 1.63 & 1.82 & 0.12 & 0.14 & 0.10 & 0.10 & 0.07 & 0.08 \\
\hline
\end{tabular}

*: Means followed by the same letter(s) within the same column are insignificantly different at 0.05 level of probability.

Table 6. Means of Seed index, No. of seeds/ capsule, No. of capsules/plant, Seed weight/plant, Seed yield/ ha and Seed oil content during $2017 / 2018$ and 2018/2019 seasons under the effect of phosphorus fertilizer rates.

\begin{tabular}{|c|c|c|c|c|c|c|c|c|c|c|c|c|}
\hline \multirow{2}{*}{$\begin{array}{c}\text { phosphorus } \\
\text { rates } \\
\left(\mathrm{kg} \mathrm{P}_{2} \mathrm{O}_{5} / \mathrm{ha}\right)\end{array}$} & \multicolumn{2}{|c|}{$\begin{array}{l}\text { Seed index } \\
(\mathrm{g})\end{array}$} & \multicolumn{2}{|c|}{ No. of seeds/ capsule } & \multicolumn{2}{|c|}{ No. of capsules/plant } & \multicolumn{2}{|c|}{$\begin{array}{c}\text { Seed weight/plant } \\
\text { (g) }\end{array}$} & \multicolumn{2}{|c|}{$\begin{array}{c}\text { Seed yield/ha. } \\
\text { (t/ha) }\end{array}$} & \multicolumn{2}{|c|}{$\begin{array}{c}\text { Seed oil } \\
\%\end{array}$} \\
\hline & $2017 / 18$ & $2018 / 19$ & $2017 / 18$ & $2018 / 19$ & $2017 / 18$ & $2018 / 19$ & $2017 / 18$ & $2018 / 19$ & $2017 / 18$ & $2018 / 19$ & $2017 / 18$ & $2018 / 19$ \\
\hline Zero & $9.0 \mathrm{c}^{*}$ & $10.03 \mathrm{c}$ & $9.23 \mathrm{c}$ & $9.45 \mathrm{c}$ & $18.5 \mathrm{c}$ & $16.57 \mathrm{c}$ & $0.59 \mathrm{c}$ & $0.61 \mathrm{c}$ & $1.828 \mathrm{c}$ & $1.803 \mathrm{c}$ & $45.09 \mathrm{c}$ & $45.08 \mathrm{c}$ \\
\hline 36 & $9.50 \mathrm{a}$ & $10.95 \mathrm{a}$ & $9.70 \mathrm{a}$ & $9.87 \mathrm{a}$ & $20.75 \mathrm{a}$ & $20.34 \mathrm{a}$ & $1.03 \mathrm{a}$ & $0.90 \mathrm{a}$ & $2.514 \mathrm{a}$ & $2.362 \mathrm{a}$ & $46.51 \mathrm{a}$ & $46.68 \mathrm{a}$ \\
\hline 72 & $9.21 \mathrm{~b}$ & $10.51 \mathrm{~b}$ & $9.46 \mathrm{~b}$ & $9.70 \mathrm{~b}$ & $20.01 \mathrm{~b}$ & $18.53 \mathrm{~b}$ & $0.77 \mathrm{~b}$ & $0.74 \mathrm{~b}$ & $2.111 \mathrm{~b}$ & $2.120 \mathrm{~b}$ & $45.52 \mathrm{~b}$ & $45.81 \mathrm{~b}$ \\
\hline L.S.D.(0.05) & 0.20 & 0.33 & 0.19 & 0.15 & 0.36 & 0.36 & 0.04 & 0.03 & 0.25 & 0.23 & 0.09 & 0.09 \\
\hline
\end{tabular}

*: Means followed by the same letter(s) within the same column are insignificantly different at 0.05 level of probability. 
Table 7. Means of Seed index, No. of seeds/ capsule, No. of capsules/plant, Seed weight/plant as affected by the interaction between sowing dates and phosphorus fertilizer rates.

\begin{tabular}{|c|c|c|c|c|c|}
\hline \multirow{2}{*}{$\begin{array}{l}\text { Treatment } \\
\text { sowing dates }\end{array}$} & & \multirow{2}{*}{$\begin{array}{c}\begin{array}{c}\text { Seed index } \\
(\mathrm{g})\end{array} \\
2018 / 19\end{array}$} & \multirow{2}{*}{$\begin{array}{c}\text { No. of seeds/ capsule } \\
2018 / 19 \\
\end{array}$} & \multicolumn{2}{|c|}{$\begin{array}{c}\text { Seed weight/plant } \\
(\mathrm{g})\end{array}$} \\
\hline & $\begin{array}{c}\text { phosphorus rates } \\
\left(\mathrm{kg} \mathrm{P}_{2} \mathrm{O}_{5} / \mathrm{ha}\right) \\
\end{array}$ & & & 2017/18 & $2018 / 19$ \\
\hline \multirow{3}{*}{ 1st Nov. } & Zero & $9.70 c^{*}$ & $9.34 \mathrm{~d}$ & $0.55 \mathrm{f}$ & $0.53 \mathrm{~g}$ \\
\hline & 36 & $9.92 \mathrm{c}$ & $9.47 \mathrm{~cd}$ & $0.74 \mathrm{~cd}$ & 0.64 ef \\
\hline & 72 & $9.88 \mathrm{c}$ & $9.37 \mathrm{~d}$ & $0.78 \mathrm{bc}$ & $0.69 \mathrm{de}$ \\
\hline \multirow{3}{*}{ 15th Nov. } & Zero & $10.59 \mathrm{~b}$ & $9.70 \mathrm{bc}$ & $0.65 \mathrm{e}$ & $0.68 \mathrm{~d}$ \\
\hline & 36 & $11.06 \mathrm{~b}$ & $9.92 \mathrm{~b}$ & $1.19 \mathrm{a}$ & $1.12 \mathrm{a}$ \\
\hline & 72 & $10.97 \mathrm{~b}$ & $9.88 \mathrm{~b}$ & $0.83 \mathrm{~b}$ & $0.81 \mathrm{c}$ \\
\hline \multirow{3}{*}{ 30th Nov. } & Zero & $9.82 \mathrm{c}$ & $9.31 \mathrm{~d}$ & $0.57 \mathrm{f}$ & $0.62 \mathrm{f}$ \\
\hline & 36 & $11.87 \mathrm{a}$ & $10.22 \mathrm{a}$ & $1.16 \mathrm{a}$ & $0.94 \mathrm{~b}$ \\
\hline & 72 & $10.68 \mathrm{~b}$ & $9.85 \mathrm{~b}$ & $0.70 \mathrm{de}$ & $0.72 \mathrm{~d}$ \\
\hline
\end{tabular}

*: Means followed by the same letter (s) within the same column are insignificantly different at 0.05 level of probability. 
However, in the third sowing date, both traits showed significant increase in their values up to $36 \mathrm{~kg}$ P2O5/ha, while further increase to $72 \mathrm{~kg} \mathrm{P} 2 \mathrm{O} / \mathrm{ha}$ led to a significant decrease in values of both traits. That may be explained by the ability of phosphorus to mitigate the effect of high temperature at seed setting and filling for late sowing, thus increasing phosphorus fertilizer rates above $36 \mathrm{~kg}$ P2O5/ha decrease values of studied traits, i.e., seed index, number of seeds/capsule and seed weight / plant, due to the imbalance nutritional effect of applying $72 \mathrm{~kg} \mathrm{P} 2 \mathrm{O} 5 / \mathrm{ha}$ of phosphorus with low $\mathrm{N}$ application (110 kg N/ ha) on plant growth and development. Similar findings were reported by Fageria and Stone (2006).

\section{CONCLUSION}

The results could be concluded that the $15^{\text {th }}$ Nov. sowing date combined with $36 \mathrm{~kg} \mathrm{P}_{2} \mathrm{O}_{5} / \mathrm{ha}$ was dominated over the other two sowing dates and two phosphorus fertilizer rates in all seed yield /ha and its components.

\section{REFERENCES}

A.O.C.S: American Oil Chemists Society. 2004. Official Methods and Recommended Practices of the American Oil Chemists Society (4 $4^{\text {th }}$ ed.). Champaign: American Oil Chemists Society.

Abd El-Mohsen, A.A., A.M. Abdallah and G.O. Mahmoud. 2013. Optimizing and describing the influence of planting dates and seeding rates on flax cultivars under Middle Egypt Conditions. World Essays J. 1 (4): 142- 152. Available online at www.worldessays.j.com.

Adugna, W. and M. T. Labuschagne. 2003. Association of linseed characters and its variability in different environments. J. Agric. Sci. 140 (3) : 285-296.

Agriculture Extension. 2010. Flax growing and production. Extension News for Field Crops, Information Unit, Extension Management, Ministry of Agriculture, Egypt, Info-unit@cace-eg.com.

Askar, G., S.A. Abdullah, T.B. Khalil, F. Moslem and B. Bahare. 2013. Effect of delaying in sowing date on growth, yield, yield components and oil content of two genotypes of flax seed (linum usitatissimum L.). Advances in Environmental Biology., 7 (6): 1014- 1018.

Casa, R., G. Russell, B. Lo cascio and F. Rossini. 1999. Environmental effects on linseed (linum usitatissimum L.) yield and growth of flax at different stand densities. Eur. J. Agron., 11 (3-4): 267- 278.

Choudhary, A.A., R.R. Nikam and S.S. Patil. 2016. Effect of phosphorus and sulphur on oil, nutrient uptake and yield of linseed. Int. J. Life Sci., Special Issus A6 (Nat. Conf. Innovat. in Agri-Biosci., NCIABS).

Dybing,C.D., P. D. Evenson and C. Lay. 1988. Relationships among daily flower production, length of the flowering period, and seed yield of flax. Crop Sci. 28. (2): 287-292.
El-Nakhlawy. F.S. 1995a. Studies on seed yield, protein and oil contents and fatty acid composition of twenty-four flax varieties .Menofiya J.Agric.Res., 20: 83-93.

El-Nakhlawy, F.S. 1995b. Response of flax to foliar fertilization. Com. In. \& Dev. Res., 49:1-12.

El-Nakhlawy, F.S. 2010. Experimental Design and Analysis in Scientific Research. Sci.Pub.Center, King Abdulaziz Univ., Jeddah, Saudi Arabia.

El-Nakhlawy, F.S. and M.H. Shiboob. 2011. Evaluation of nine oil crops for fatty acid constituents of their oils. JKAU: Met., Env. \& Arid land Agric. Sci. 22(1):51-59.

El-Refaey, R.A., E.H. El-Seidy, I.A.E. El-Deeb. 2010. Effect of sowing dates under different environment conditions on yield and quality of some flax genotypes. Alex. J. Agric. Res., 55 (2): 33-41.

FAO. 2019. FAOSTAT online database. Food and Agriculture Organization of the United Nations Resources, Rome, Italy. http://faostat.fao.org/.

Fageria, N.K., and L.F. Stone. 2006. Physical, chemical, and biological changes in the rhizosphere and nutrient availability. J. Plant. Nutr., 29: 1327-1356.

Fleisher, D.H., Q. Wang, D.J. Timlin, J.A. Chun, and V.R. Reddy. 2013. Effects of carbon dioxide and phosphorus supply on potato dry matter allocation and canopy morphology. J. Plant Nutr., 36: 566- 586.

Garsid, A. 2004. Sowing time effects on the development, yield and oil of flax seed in semi arid tropical. Aust. J. Prod. Agric., 23: 607- 612.

Grant, C.A., M. A. Monreal, R. B. Irvine, R. M. Mohr, D. L. McLaren and M. Khakbazan. 2009. Crop response to current and previous season applications of phosphorus as affected by crop sequence and tillage. Can. J. Plant Sci., 89: 49-66.

Hocking, P.J., and A. Pinkerton. 1993. Phosphorus nutrition of linseed (Linum usitatissimum L.) as affected by nitrogen supply: Effects on vegetative development and yield components. Field Crops Res. 32: 101- 114.

Jiao, Y., A.G. Cynthia, and D.B. Loraine. 2007. Growth and nutrient response of flax and durum wheat to phosphorus and zinc fertilizers. Can. J. Plant Sci., 87: 461-470.

Lafoand, G.P., C.A. Grant, A.M. Johnton, D.W. Mcandrew and W.E. May.2003. Nitrogen and phosphorus fertilizer management of no-till flax. Better Crops, 87(1):6-11

Lafond,G. P. d, Irvine , B. and A. M. Johnsto. 2008. Impact of agronomic factors on seed yield formation and quality in flax. Can. J..Plant Sci., 88 (3): 485-500.

Leilah, A.A., A.T.El- Kassaby, M.H. eL-Hinid and T.A.AbuZaid. 2003. Requirement of some flax cultivars from NPK fertilizers. Sci.J. King Faisal Univ.( Basic and Applied Sci.), 4 (2): 125- 139.

Mengel, K. and A.K. Frnest. 2010. Principles of plant nutrition. International Ptash Institute. P.O. Box, CH-3048 Worblanfen-Bern/Switzerland. 
Mirshekari, M., R. Amiri, H.I. Nezhad, S.S. Noori and O.R. Zandvakili. 2012. Effects of planting date and water deficit on quantitative and qualitative traits of flax seed. Amer.-Euras. J. Agric. \& Environ. Sci., 12 (7): 901- 913.

Morris, D.H. 2007. Description and composition of flax. FlaxA health and Nutrition Primer, pp. 10-13 Flax Council of Canada.

Mousavi, S.R. 2011. Zinc in crop production with phosphorus. Aust. J. Basic Appl. Sci., 5 (9): 1503- 1509.

Ottai, M.E.S., M.A.A. Al-Kordy and S.A. Afiah. 2011. Evaluation, correlation and path coefficient analysis among seed yield and its attributes of oil flax (Linum usitaissimum L.) genotypes. Aust. J. Basic and Applied Sci., 5 (11): 252- 258.
Rogério, F., T. R. B. Silva, J.I. Santos, and J.P. Poletine. 2013. Phosphorus fertilization influences grain yield and oil content in crambe. Ind. Crops Prod., 41: 266- 268.

SAS. 2007. SAS Institute, Inc. SAS Technical Report SAS/STAT Software; Changes and enhancements users guide. Volume 2, Version 9.1.3, Fourth Edition, Cary, NC: SAS Institute Inc.

Xie, Y., X. Niub and J. Niu. 2016. Effect of phosphorus fertilizer on growth, phosphorus uptake, seed yield, yield components, and phosphorus use efficiency of oil seed falx. Agron. J., 108 (3): 1257- 1266.

Xie, Y.P., J.Y. Niu, Y.T. Gan, Y.H. Gao, and A.R. Li. 2014. Optimizing phosphorus fertilization promotes dry matter accumulation and $\mathrm{P}$ remobilization in oilseed flax. Crop Sci. 54: 1729- 1736.

You, J.; A.G. Cynthia and D.B. Loraine. 2007. Growth and nutrient response of flax and durum wheat to phosphorus and zinc fertilizers. Can. J. Plant Sci., 87 (3): 461 - 470. 


\section{الملخص العربي}

\section{تاثير موعد الزراعة ومعدلات السماد الفوسفاتى على المحصول ومكوناته لصنف الكتان سخا ه} منى محمد حميد

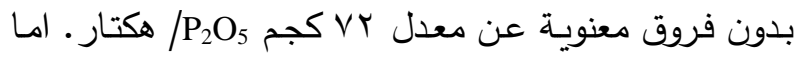

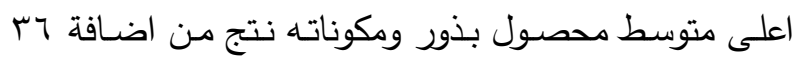
كجم / $\mathrm{P}_{2} \mathrm{O}_{5}$ ككتار و بفروق معنويـة عن المعدلين الاخرين وبالنسبة لمحتوى البذور من الزيت فقد اعطى المعدل بس كجم

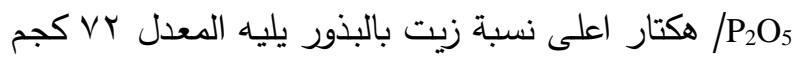

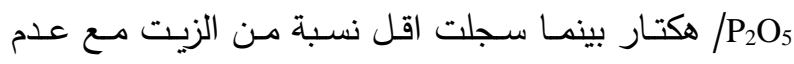
اضافه سماد فوسفاتى (صفر كجم للهكتار). بالنسبة للصفات التى تاثرت معنويا بالتفاعل بين عاملى الدراسـة فقد وجد ان

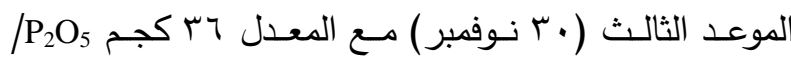
هكتار اعطى اعلى القيم فى صفة معامل البذرة وعدد البذور للكبسولة وذلك فى الموسم الثانى اما صفة وزن بذور النبات فقد سجلت أعلى قيم لها مـع كل من الموعد الثانى والثالث

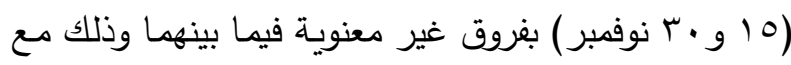

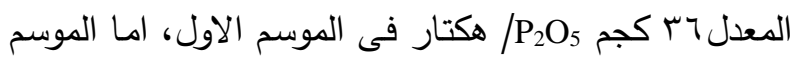
الثانى فقد كان اعلى وزن بذور للنبات مع الموعد الثانى (10) نوفمبر ) والمعدل צس كجم
اجريــت هـــه الدراســه بمزرعــة كليـة الزراعـة- جامعـة

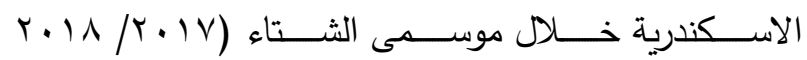

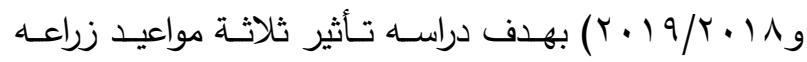

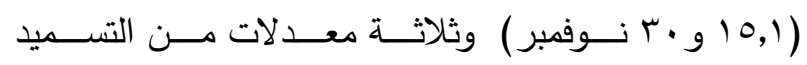

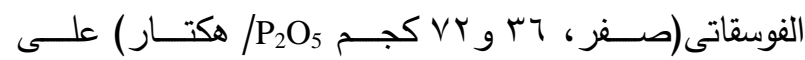
محصولى القش والبذور ومكوناتهما بالاضافه لمحتوى البذور من الزيت وذلك فى صنف الكتان سخا ه ـ ـاوضحت النتائج معنويسة ت تـأثير كـل مـن موعـد الزراعـة ومعـدلات التسـيد

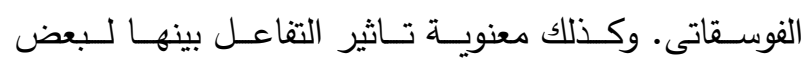
الصفات المدروسـه (معامل البذرة وعدد البذور / كبسولة فى ولى

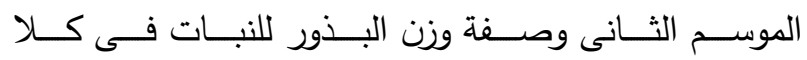
الموسـين).كما اوضـــت النتـائج ان موعـدى الزراعـة الاول

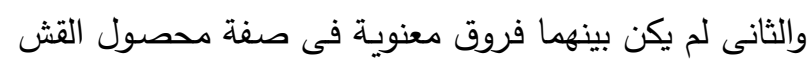

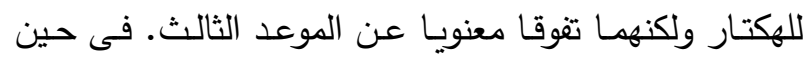
تفوق الموعد الثانى(0 انوفمبر) فى كل من عدد الكبسولات للنبات ومحصول البذور للهكتار مقارنـة بالموعدين الاخرين. كذلك اظهرت النتائج ان استخدام بس كجم الى الحصول على اعلى محصول من القش ومكوناته ولكن 